\title{
DETERMINANTS OF THE INDUSTRIAL MANUFACTURING STOCK'S HOLDING PERIOD
}

\author{
Rima Islamiah \\ Faculty of Islamic Studies, Universitas Muhammadiyah \\ Surakarta \\ email: rima.islamiah@gmail.com
}

\section{ABSTRACT}

This study aims to identify the effect of Market Value (MV), Return on Asset (ROA), Earning per Share (EPS) and Bid-Ask Spread (BAS) over the holding period of manufacturing companies listed in Jakarta Islamic Index (JII). The data used here is period between 2014-2016. This research is a quantitative research. The data used in this research are the outstandingnumber of shares, the volume of stock transactions, closing price, ROA, and EPS. The technique for data analysis which will be used in this research is panel data regression test using REM model. The results of this study show that: 1). Market value have a significant positive effect on the manufacturing company stock's holding period, which is shown by the value of sig t 0,0075 . 2). ROA has no significant effect on on the manufacturing company stock's holding period, which is shown by the value of sig t 0.1269 . 3). EPS did not significantly affect the holding period of the manufacturing company's shares which was shown by the sig t value 0.7358 . 4). The variable of Bid-Ask Spread does not significantly affect the holding period of the manufacturing company's stock which is shown by the value of sig t 0.1031. 5). MV, ROA, EPS, BAS according to test of model existence / $\mathrm{F}$ test is the existing model used with the value of $F$ statistics 0.000397 . 5). The value of Adjusted R2 of $19.85 \%$ indicates that variations in the variable of Holding Period can be explained by independent variables, and the remaining $80.65 \%$ of 
the variable of Holding Period are explained by other variables outside the research model.

Keywords: Holding period, Market value, REM modelling, Jakarta Islamic Index.

\section{INTRODUCTION}

The capital market is a market for various long-term tradable financial instruments, such as bonds, equities (stocks), mutual funds, derivative instruments and other instruments. The stock market is also called the Securities Exchange, because there is a sale and purchase of securities. Stock exchange itself is the physical capital market. The Indonesian Stock Exchange provides various types of securities offered by the company and they can be selected by investors in accordance with their various consideration (Sari and Abundati, 2015).

An investor has the freedom to choose the type of stock, buy the number of shares and determine the length for holding financial assets. If investors know that stocks of the companies they buy are profitable, then they will likely hold those shares for longer periods, in the hope that the future selling price of these shares will be higher. By contrary, investors will soon release the shares they have bought, if they predict the price of those shares will decline. They will do this because by doing this they canget bigger gain on the investment made and to minimize risks that will be faced (Arma, 2013). The length of period in which an investor holds companies stock or or other finansial asset is known as Holding Period (Sari and Abundati, 2015).

One of the stock indexes available in the Indonesian Stock Exchange is the Jakarta Islamic Index (JII). Companies listed in this index are companies that have the criteria in accordance with 
the principles of Sharia. The data below shows the growth in the volume of shariah stock transactions filtered by JII index.

Table 1. Companies and Their Volume of Transaction in 2014-2016

\begin{tabular}{ccc}
\hline Year & Number of companies & Volume oftransaction (billion) \\
\hline 2014 & 30 & 239,894 \\
2015 & 30 & 240,793 \\
2016 & 30 & 463,405 \\
\hline
\end{tabular}

Source: www.idx.co.id.

This shows that the interest of investors to invest in Sharia stocks is getting bigger. Although the interest of investors to transact Sharia stocks is quite large, but that does not meanthat to hold thosestocks can be fully profitable. At some point, an Islamic stocks must be worthy of an investor's hold for a certain period of time to show that the investor feels secure in holding the stocks. From this background, the writer is interested to do this research by taking several similar variables and using the related research about Holding Period of shares Manufacturing companies stocks.

\section{LITERATURE REVIEW}

\section{Previous Studies}

To begin this research, I will be benefiting from previous literature as a reference in conducting further research. No previous research is exactly the same as what I wil be undertaking. However, some previous research can be used as reference and learning material for researchers in preparing advanced research.

Visita Yales A (2013) in his research entitled Faktor Penentu Holding Period Saham LQ-45 Di Bursa Efek Indonesia discusses what are determining factors for the length of Holding Period. By using variables like, BAS, Market Value, Variance Return, 
his study explains that the BAS variable has no significant effect on the Holding Period, which illustrates that investors will hold stocks with long time. The character of these stocks, are among others, of a higher market value and of shorter time when having a higher risk.

Ni Luh Ayu Y U and Ida Bagus Panji S (2016) in his research entitled Pengaruh Spread, Market Value, Variance Return (VR), Devidend Payout Ratio (DPR) terhadap Holding Period Saham discussed some independent variables like Spread, MV, VR, DPR, whether they have significant effect on Holding Period. The results of this study indicate that investors should consider two variables; that is Market Value and House of Representatives in order to predict exactly the benefits that will be gained, especially in basic and chemical industry sectors.

Novita Selvia M Warin-angin and Syarief Fauzie (2013) discussed the effect of BAS, Market Value, and Variance Return on Mining Sector Holding Period. By using variables like BAS, $\mathrm{MV}$, and VR, the results of this study indicate that these variables greatly affect the holding period in the mining sector.

Ely Winda Sari and Nyoman Abundanti (2015) studiedabout the Determinants of Holding Period Determinants On LQ45 Index. They used some independent variables, such as BAS, MV, House, Risk of Return, Earning per Share. The results of this study indicate that internal and external factors also affect the Holding Period, in order to obtain optimal return.

Ade Nahdiatul Hasanah (2016) analysed the Effect of Transaction Cost on Holding Period of LQ45 Shares in Indonesia Stock Exchange (IDX). Using independant variables like BAS, MV, VR, Devidend Yield, Earning per Share, the results of 
this study states that in taking a decision about the duration of holding common shares in the BEI, one should also see the macro economic conditions. Because when economic conditions are uncertain, investors should be careful in holding or selling stocks that have a more dominant risk.

\section{Definition of Invesment Activities}

Investment, conceptually, is a commitment to a number of funds or other resources at this moment with the aim of gaining profit in the future. Thus, in the other words, it is to invest money now, in order to get benefits (reward or profit) in the future. Investment means the expenditure of investors or companies to purchase capital goods and production equipment to increase the ability to produce goods and services available in the economy (Sukirno, 1997).

Investments are also defined as expenditures to purchase capital goods and production equipment in order to replace and primarily to add the capital goods in the economy that will be used to produce goods and services in the future. In the theory of investment economy, it is a shopping activity to increase the capacity to produce something in the economy (Sukirno and Sadono 2005).

Definition of Investment by Kamus Besar Bahasa Indonesia (KBBI), is putting the money in a company or project for the purpose of obtaining profit. It is basically to buy an asset that is expected in the future to be resold at a higher value. It can also be interpreted as the placement of funds or the exchange of money with other forms of wealth over a certain period, which is expected to earn income and / or increase the value of investment. 
As a delay of consumption of the present for the foreseeable future, in which there is a risk, it requires a compensation for the delay, in the form of profit.

In general, the object of investments is real assets (land, gold, and buildings) as well as financial assets (securities or securities). Investors have the freedom to choose the type of securities to invest in a go public company. Investors also have the freedom to determine the amount of securities they buy and the duration of holding or holding such securities. Those who feel the securities they buy will bring profits, will hold the securities for a longer period of time, or immediately release the securities if it is predicted to be less profitable (Sari \& Abundati, 2015).

There is relationship between investment and consumption, because the delay of consumption is an investment in the future, then below is a curve that explains about this (Fauzan, 2005).

Figure 1. Indefference Curve Of Current and Future Consumption

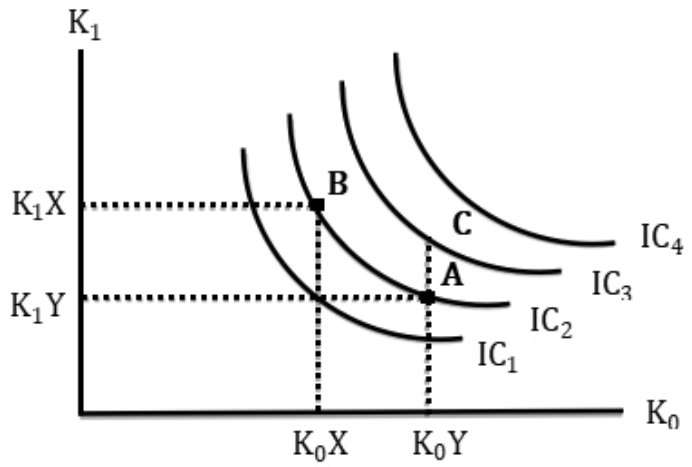

Source: Fauzan, et all. (2005) in Buku Pengantar Teori Investasi dan Pasar Modal

Investment and consumption are two interrelated activities. The current consumption delays can be interpreted as an investment for future consumption. It can be described with 
indefference curve, i.e. a curve that shows the same satisfaction (utility) for each point. Figure 2.1 shows that the combination of current consumption $\left(\mathrm{K}_{0}\right)$ and upcoming consumption $\left(\mathrm{K}_{1}\right)$ gives the same satisfaction at points along the indefference curve. Both point $\mathrm{A}$ for a combination of current and future consumption $\left(\mathrm{K}_{0} \mathrm{Y}\right.$ $\& \mathrm{~K}_{1} \mathrm{Y}$ ) and point $\mathrm{B}$ for a combination of current and upcoming consumption $\left(\mathrm{K}_{0} \mathrm{X} \& \mathrm{~K}_{1} \mathrm{X}\right)$ will provide the same level of satisfaction. Point $A$ has a current level of consumption $\left(\mathrm{K}_{0} \mathrm{Y}\right)$ greater than the current consumption level $\left(\mathrm{K}_{0} \mathrm{X}\right)$ at point $\mathrm{B}$. Vice versa, point $\mathrm{B}$ has an upcoming consumption level $\left(\mathrm{K}_{1} \mathrm{X}\right)$ greater than the next level of consumption at point $\mathrm{A}$. Point $\mathrm{C}$ is a combination of consumption that has the highest degree of satisfaction, since point $\mathrm{C}$ lies on $\mathrm{IC}_{3}$ position above the other indifferencecurve $\left(\mathrm{IC}_{1} \mathrm{IC}_{2}\right)$. Point $\mathrm{A}$ and point $\mathrm{C}$ have an upcoming level of consumption higher than point $\mathrm{A}$.

\section{Definition of Sharia Investment}

Investment in the view of Sharia is slightly different, in that it is Sharia itself that has anauthoritative rule in running a good and perfect life. It can be achieved by maintaining human relationships and other creatures, in which all of this are all carried out in the framework of good relationships with God.

Islam has a different view about investment, especially in the use of wealth. In addition, the concept of wealth in Islam is also not the same as the Western view. The difference between Islamic views and that of Western views is related to God's position. In the Western view, God is put aside. He is beyond human capacity to be known. Everything happens with the power of human effort. The rationality of the individuals becomes the driving force of all activity. 
The concept of Islamic investment is the concept of investment in accordance with the guidance of Religion of Islam. Therefore, it is necessary to consider the aspects that will become the determinants of investment activities, normative aspects that trigger the investment activities, the conception of wealth and the usage of wealth. Investments in Islamic perspective can only be done on instruments that are in accordance with Sharia and they must not contain usury. Investments can also be made only on securities issued by the issuer whose type of business activities are not contrary to Sharia.

Sharia Investment in the capital market means an investment activity in securities which conform Islamic principles that have received recognition from the DSN (National Sharia Council). The definition Sharia Investment in general according to Veithzal Rivai, et al (2010) is the activity to increase money through the utilization of various sources with the intention of gaining profit that is in line with Islamic principles.

Apart from paying attention to the issuer, we should also see carefully the types of investment transactions since there are several types of transactions which are prohibited. The selection and execution of investment transactions must be carried out according to prudential management principles and it is not allowed to make speculations that are contrary to sharia principles. There are several shariah compliance products in the Islamic investment area, among others are Mudharabah Deposits, Asuransi Syariah , Education Savings, Syariah Mutual Funds, Sharia Shares, Gold Investment. 


\section{Definition of Capital Market}

Capital market is a market for various long term instruments that can be exchanged, including bonds, shares, mutual funds and any other instruments. Capital market is a funding facility for companies, institutions (including those government institutions) as it is a facility for investment activity as well (Rivai, 2010).

According to Act no.8 Year 1995 on Capital Market, it is stated there that capital market is "an activity related to the public offering, trading on issued securities and other body and professions related to the securities (article 1 point 13). The securities itself is issued shares, debt certificates, commercial debt certificates, stocks, bonds, debt receivables certificates, collective investment funds, future contracts on stocks and any other derivative with stocks as it underlying units (article 1 point $5)$.

Capital market is a compliment for other two industries within financial sector, the banking and insurance industry. It bridges the capital owner called investor and the fund users called stock issuers or simply those companies which went public (Hermuningsih, 2012).

Capital market is a market for various instruments and long term securities which can be traded, whether in the form of debt or capital, whether it issued by government, public authorities or private companies (Husnan, 1994).

\section{Definition of Islamic Capital Market}

According to Burhanuddin, the word capital from the fiqh perspective means all things (property or asset possession) which 
has the capable of producing another asset. The capital market is a place of buying and selling the securities with the purpose of getting profit for both buyer and seller under the umbrella of Islamic principles (S, 2008.)

Islamic capital market is one of the alternative funding resources for companies while in the same time it is an investment facility for the investors by using contracts comply to the shariah requirement that DSN-MUI (National Shariah Advisory Council) has enacted (Umam, 2013).

The Islamic principles for capital market activities according to the fatwa of DSN-MUI, whether the laws enacted under the Law of Supervisory Body for Capital Market and Financial Institutions (Bapepam LK) or DSN-MUI's fatwa introduced prior to the Decision of Bapepam LK Number: KEP/-130/BL/2006 on Shariah Securities Issue.

According to Umam (2013), the activities in the capital market can be classified under the mu'amalah type of economic activity that is a type which manages the trading in the daily life. The legal maxim of fiqh asserted that the basic principle in the mu'malah is mubāh (permissible) based on the postulate "All mu'amalah activities are basically permissible unless it is mentioned otherwise by the other proof (dali $l)$.

According to fatwa of DSN-MUI number 40/DSN$\mathrm{MUI} / \mathrm{X} / 2003$, Islamic securities mean the securities which is mentioned under national law of capital market specifically for those securities with the contracts, company management and the issuing steps conforms the Islamic principle.

The prohibition in financing and investment activities according to shariah include transaction containing riba and that is the reason why the transaction in the capital market must be 
free from riba. Other activities also include those which contain speculation and garar element or uncertainty that is the transaction which might have the cheating aspect.

In general, capital market activity in Indonesia is not much different from the capital market in general. Islamic capital market operate under the Islamic principle stipulated under BapepakLK rule number IX.A.13 which states that Islamic principles in capital market activities are based on the Fatwa of DSN-MUI as long as the prescribed fatwa is not contraty to the Bapepam-LK regulations. ${ }^{1}$

\section{Stocks or shares}

Stocks are the certificate indicating proof of ownership of a company, and shareholders have a right to claim on the earnings and assets of the company. Stock prices are affected by the law of demand and supply. The stock price may increase if it is overdemand and tends to decrease if it experiences an excess supply (Umam, 2013). Shares may also be construed as a certificate of capital participation of a person or legal entity against a company, and is a written evidence for investors on the ownership of a company which has gone public (S, 2008).

The stock in Islam is essentially a modification of the joint venture system of capital and wealth, which in fiqh terms is known as syirkah or cooperation (S, 2008). Sharia stock is securities or securities that have the concept of equity participation to companies that do not have activities or business activities that violate sharia principles with the right of profit sharing based on sharia principles (Heykal, 2012).

${ }^{1}$ Note that Bapepam-LK is currently replaced by OJK (Financial Services Authority). 


\section{Holding Period of Stocks}

Financial investment in the form of stocks has a high level of risk if investors are not careful. This makes investors have to decide the length of time they should hold the shares (holding period) in order to obtain the expected profit levels. Holding period of shares is the length of time investors are willing to hold assets or securities by taking into account the profits and losses gained (Rianto \& Hutomo, 2008).

Holding period of shares is the length of time the investor is willing to hold the asset or the securities by taking into account the gains and losses earned. Holding period of stock is shown by comparison between the number of shares outstanding with the volume of stock transactions. The figure indicated from the holding period of the stock does not mean that an investor holds its stock for that with certainty, but the figure indicates that the greater the nominal price, the longer the length of time an investor holds the stock.

Investors activities of holding and selling their stocks is done to maximize their profit or to reduce the risk they will face. The length of period holding their fund in certain securities is called as holding period and the each investor has their investment analysis in determining of holding or selling the securities they have.

Holding period is the variable that indicates the average length an investor hold the shares of certain companies he has. When an investor is about to invest, he must look ahead towards the return expected. The high fluctuation rate of trade transaction volume indicates the investors decision on holding period which keeps changing over the time. The high volume of trade transactions indicating that investors are often traded which also 
means that investors do not hold shares in longer periods of time (Ningsih and Asandrimitra, 2017).

Holding period adalah variabel yang mengindikasikan mengenai rata-rata lamanya waktu investor dalam memegang saham suatu perusahaan yang dimilikinya. Ketika Seorang investor akan melakukan investasi, tentunya mereka juga akan menginginkan pengembalian (return) sesuai yang diharapkan. Tingkat fluktuasi volume transaksi perdagangan yang tinggi mencerminkan keputusan investor terhadap holding period suatu saham yang berubah-ubah. Tingginya Volume transaksi perdagangan menunjukkan bahwa saham yang dimiliki investor sering diperjualbelikan yang juga berarti bahwa investor tidak menahan sahamnya dalam kurun waktu yang lebih lama (Ningsih \& Asandrimitra, 2017).

\section{Jakarta Islamic Index (JII)}

Jakarta Islamic Index (JII) consists of 30 companies that fall within the criteria of sharia (List of Sharia Securities issued by OJK) and includes shares with large capitalization and high liquidity. JII was formed from the cooperation between PT. BEI (it was Bursa Efek Jakarta during that time) with PT Danareksa Investment Management (PT DIM). JII operates since July 3, 2000. The purpose of establishment of JII is to increase investor confidence to invest in syariah-based stocks and provide benefits for investors who invest in stock exchanges (S, 2008).

The criteria in choosing stocks as JII is the shares of companies which businesses are not contrary to the shariah principle. DSN-MUI fatwa number 40/DSN-MUI/X/2003 sets the criteria of business types which are in the contrary of Islamic principle. Those businesses are 1) Gambling and any prohibited 
trade, 2) Conventional financial institution (riba-based financial institutions) including banks and conventional insurance, 3) Distributor producer and the seller of prohibited food and beverages, 4) Producer, distributor and or provider of goods and services which damages moral and has the dangerous element, 4) Doing investment on companies which has the debt to capital ratio is higher then 1 .

\section{RESEARCH METHODS}

\section{Tool and Analysis Model}

The analysis carried on this paper uses panel data regression with the econometrics model as the following:

$$
\text { HPit }=\beta 0+\beta 1 M V i t+\beta 2 R O A i t+\beta 3 E P S i t+\beta 4 B A S i t+\mu i t
$$

Where :

HP : Holding Period

MV : Market Value

ROA : Return on Asset

EPS : Earning per Share

BAS : Bid Ask Spread

i : Indicating the Companies

$\mathrm{t}$ : Indicating the timeseries from 2014-2016.

$\beta_{0,1,2,3,4,5}$ : Coefficient

$\mu \quad$ : Unobserved error term

The econometrics model above will be estimated using some stages of PLS, FEM and REM. The decision of best model will be through Chow test and Hausman test. The goodness of the model estimation includes the F-test and t-test. 


\section{Dependent Variables}

Dependent variable is a variable which is affected by the independents. The dependent variable is the main object in the research. We will estimate the dependent variable and all changes associated with it later on this paper. The dependent variable in this research is the holding period, that is the variable which indicates the average period an investor willing to hold their stocks (Ningsih and Asandrimitra, 2017). The length of an investor holding his securities is not expressed in the unit of time. Instead, holding period of stocks is expressed by the comparison between the circulating shares in time of $t$ with the transaction volume in the same year (Ningsih and Asandrimitra, 2017).

$$
\mathrm{HPt}=\frac{\text { Total circulating shares in time } \mathrm{t}}{\text { Stock transaction volume in time } \mathrm{t}}
$$

\section{Independent variable}

Independent variable is the variable which explains or affects another variable. The independent variables in this research are market value, return on asset, earning per share and bid ask spread.

\section{Source of data}

The data in this research which is compiled, used and processed is the secondary data which is obtained indirectly from the third party through any existing means available. This includes the data available from literatures, articles, journals, IDX, Yahoo finance, JII, ICMD (Indonesian Capital Market Directory) which can be accessed from www.idx.co.id and the manufacturing sector companies listed at JII. The data ranges from 2014-2016. 


\section{RESULT AND DISCUSSION}

\section{Descriptive Analysis of Choosen Independent Variables}

The holding period of manufacturing companies listed at JII experience fluctuation from 2014-2016. The fluctuation did not only happen in general, it also occurred at each company. In 2014, the longest holding period is happened for Unilever company which has been held up to 18 days. Meanwhile, the fastest holding period is experienced by Adhi Karya company which has been hold for no longer than one day. In 2015, the longest holding period is experienced by Indofood Sukses Makmur Tbk while the fastest one is experienced by Hanson International. In 2016, the longest holding period is again experienced by Unilever Tbk while the fastest holding period is experienced by Hanson International again. It is also observed that all the fastest holding period never went longer than one day.

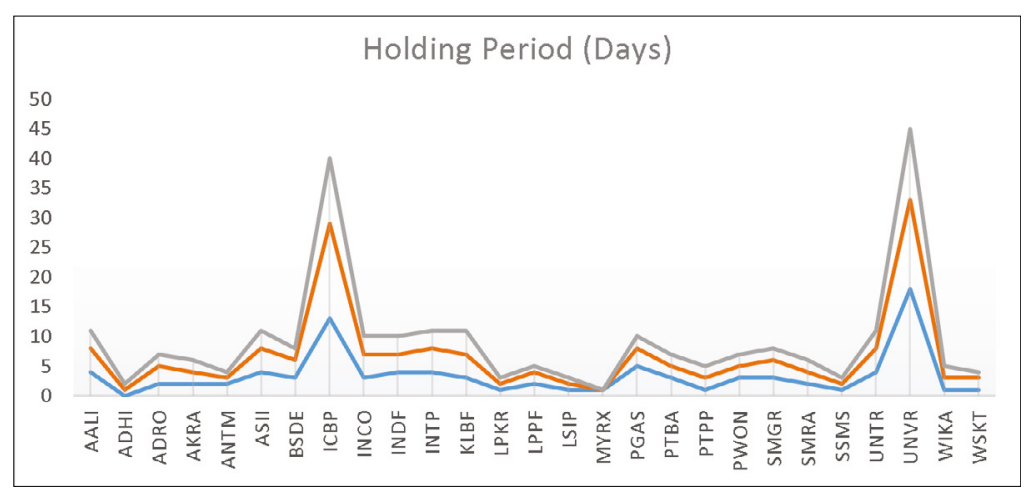

Graphic 1. Holding Period of Shares on Manufacturing Companies at JII Year 2014-2016

Just like the holding period, the market value in the finance world also experiences fluctuation. From year 2014-2016, the highest market value was 335,001 billion rupiah for the ASII 
Company. Meanwhile, the lowest market value was 2,995 billion rupiah for the ANTM Company.

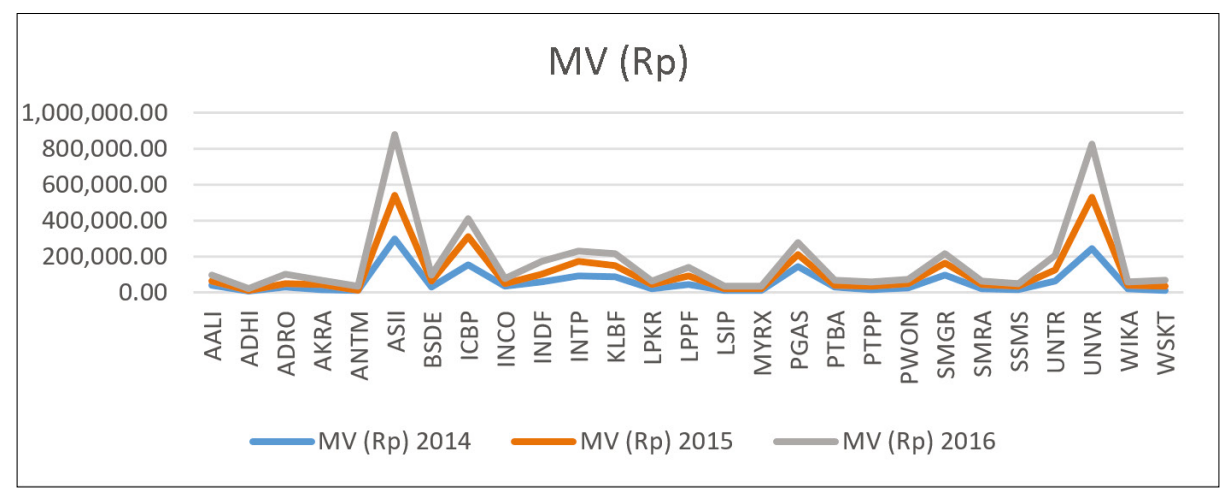

Graphic 2. Market Value (MV) of Manufacturing Companies at JII Year 2014-2016

For the ROA, the growth experienced only insignificant fluctuation from year to year. From the graphic, the data shows that the highest value of ROA from 2014 until 2016 held by Perkembangan ROA dari tahun ke tahun mengalami fluktuasi yang tidak terlalu signifikan. Matahari Department Store with the figure of $45.79 \%$. Meanwhile, the lowest ROA held by ANTM Company with the value of $-4.75 \%$

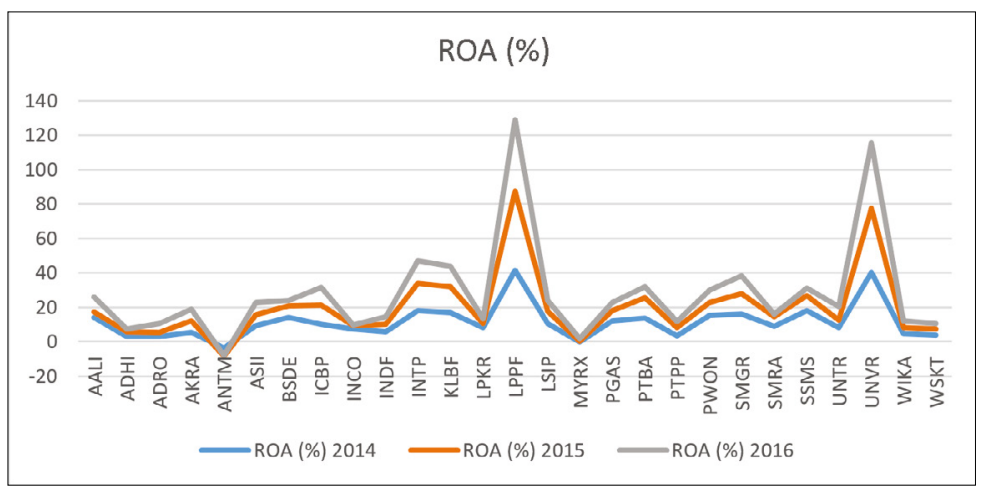

Graphic 3. Return on Asset (ROA) of Manufacturing Companies at JII Year 2014-2016 
EPS also did not experience high fluctuation through the year in each company. It is also important to be noted that the highest EPS from 2014 to 2016 held by UNTR (United Tractors) Company with the value of 1,439.50 rupiah for each piece of share. In the same time, the lowest EPS held by ANTM with the value of -81.28 rupiah per piece of share. This is because the total profit after tax is smaller compare to the issued shares during the year.

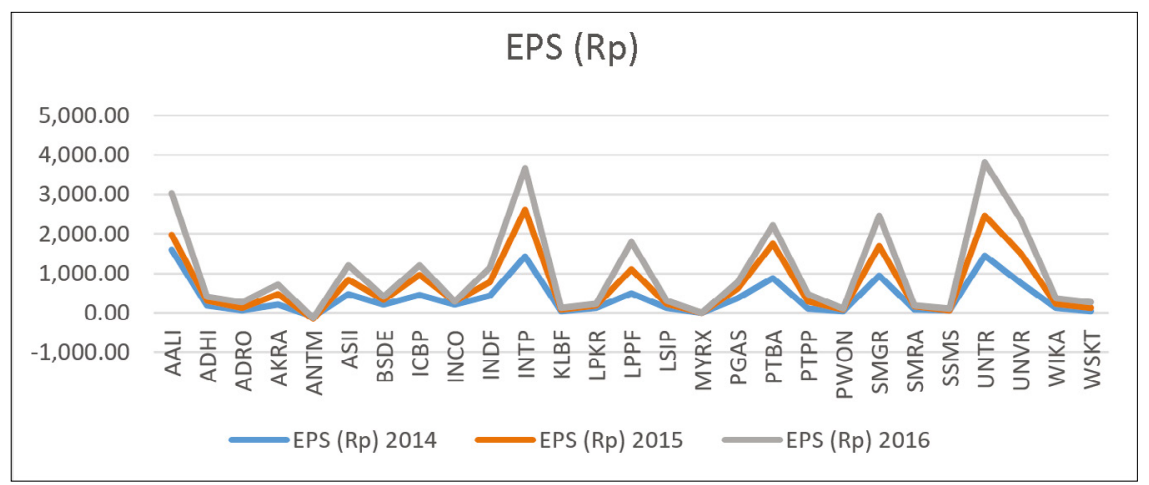

Graphic 4. Earnings per Share (EPS) of Manufacturing Companies at JII Year 2014-2016

The Bid-Ask spread experienced increase and decrease in 2014 until 2016. The highest BAS was 47,800 rupiah on three companies namely UNVR (Unilever) for year 2014 and 2016 and ADHI Company on year 2015. The lowest BAS from 2014 until 2016 was 140 which occurred on 2014 for the WYRX Company (Hanson International). 


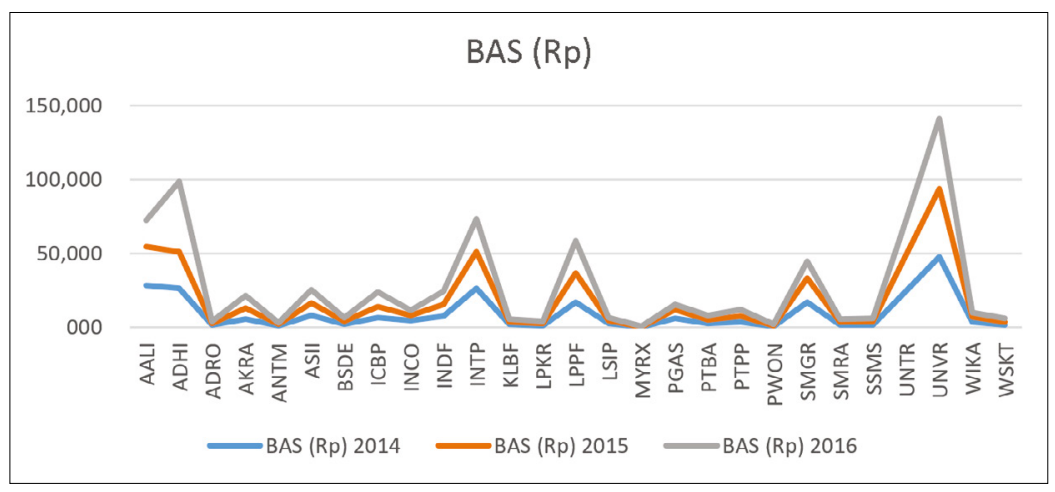

Graphic 5. Earnings per Share (EPS) of Manufacturing Companies at JII Year 2014-2016

\section{Estimation Result}

Estimation result of panel data regression on PLS, FEM or whether we have to use REM is shown on table 2

Table 2. Cross section panel data regression result

\begin{tabular}{lccc}
\hline \multirow{2}{*}{ Variabel } & \multicolumn{3}{c}{ Coefficient Model } \\
\cline { 2 - 4 } & PLS & FEM & REM \\
\hline C & 0.813969 & 2.280738 & 1.300662 \\
MV & $2.57 \mathrm{E}-05$ & $6.97 \mathrm{E}-07$ & $1.51 \mathrm{E}-05$ \\
ROA & 0.043861 & 0.062101 & 0.059839 \\
EPS & -0.000264 & $-7.56 \mathrm{E}-05$ & -0.000296 \\
BAS & $5.54 \mathrm{E}-05$ & $2.77 \mathrm{E}-05$ & $5.39 \mathrm{E}-05$ \\
R Square & 0.522446 & 0.950647 & 0.233834 \\
Adj.R Square & 0.497311 & 0.921035 & 0.193510 \\
F-stat & 20.78606 & 32.10357 & 5.798810 \\
Prob F-stat & 0.000000 & 0.000000 & 0.000397 \\
\hline
\end{tabular}

\section{Deciding the Best Estimation Model}

The step of choosing the best estimation model involves Chow test as well as Hausman test. 


\section{Chow test}

Chow test is a test used to know whether the Fixed Effect Model best suites rather than PLS. The $\mathrm{H}_{0}$ on Chow test means that the PLS is better while the $\mathrm{H}_{\mathrm{a}}$ means that the FEM is better. The $\mathrm{H}_{0}$ is accepted when $\mathrm{p}$-value $>\alpha$ while $\mathrm{H}_{0}$ is rejected when the $\mathrm{p}$-value $<\alpha$. The result of Chow test is shown at table 3 .

Table 3. Chow Test Result

\begin{tabular}{lccc}
\hline \multicolumn{1}{c}{ Effects Test } & Statistic & d.f. & Prob. \\
\hline Cross-section F & 16.685141 & $(26,50)$ & 0.0000 \\
Cross-section Chi-square & 183.843822 & 26 & 0.0000 \\
\hline
\end{tabular}

From the table 3 we can see that the p-value or the probability of F-test is 0.0000 which is lesser than 0.01 . This means that the null hypothesis is rejected. In other word, we should follow the Fixed Effect Model.

\section{Hausman test}

Hausman test is a statistical test used to determine whether FEM or REM model is needed to model a panel data equation. The null hypothesis $\left(\mathrm{H}_{0}\right)$ of Hausman test is that the model follow the Random Effect while the alternative hypothesis says that the model follows Fixed Effect. The $\mathrm{H}_{0}$ is accepted when $\mathrm{p}$-value $>\alpha$ while $\mathrm{H}_{0}$ is rejected when the $\mathrm{p}$-value $<\alpha$. The result of Hausman test is shown at table 4 .

Table 4. Hausman Test Result

\begin{tabular}{cccc}
\hline Test Summary & Chi-Sq. Statistic & Chi-Sq. d.f. & Prob. \\
\hline Cross-section random & 6.650197 & 4 & 0.1556 \\
\hline
\end{tabular}


From table 4 we can see that the p-value of Chi-Square is 0.1556 which is greater than 0.1 . Thus, the null hypothesis where random effect suits best for the model stands. From both test of Chow test and Hausman test, the Random Effect Model is chosen as the best way to model the equation in our case.

\section{REM Estimation Result}

As it has been discussed earlier, REM fits best for the equation in our case. The regression result on Random Effect Model is shown at table 5 (Note that the constants of all equation is attached in the appendix part).

Table 5. Estimation result on REM

\begin{tabular}{c}
$\mathrm{HP}_{\mathrm{i}}=1.300662+1.51 \mathrm{E}-05 \mathrm{MV}_{\mathrm{i}}+0.059839 \mathrm{ROA}_{\mathrm{i}}-0.000296 \mathrm{EPS}_{\mathrm{i}}+5.39 \mathrm{E}-05 \mathrm{BAS}_{\mathrm{i}}$ \\
$(0.0075)^{* *}+(0.1269)-(0.7358)+(0.1031)$ \\
\hline $\mathrm{R}^{2}=0.233834 ; \mathrm{DW}-\mathrm{Stat}=1.711942 ; \mathrm{F}-\mathrm{Stat}=5.798810 ;$ Sig. F-Stat $=0.000397$ \\
\hline Note: ${ }^{*}$ significant at $\alpha=0,01 ; * *$ Significant at $\alpha=0,05 ; * *$ Significant at $\alpha$ \\
$=0,10 ;$ Number inside the brackets shows the t-test probability.
\end{tabular}

Before discussing the estimation result, we first will elaborate on the validity test of the result first using t-test. The t-test shows the significant level of the independent variable individually on towards the dependent variable. $\mathrm{The}_{0} \mathrm{H}_{0}$ means that the independent variable has no significant effect on the dependent variable while the $\mathrm{H}_{\mathrm{a}}$ means that the independent variable affects significantly on the dependent variable. The $\mathrm{H}_{0}$ is rejected when the t-test $<\alpha$ and the $\mathrm{H}_{0}$ is accepted if $\mathrm{t}$-test $>\alpha$. 
Table 6. Validity Test on the Effect of Independent Variables

\begin{tabular}{ccccc}
\hline Variabel & T & Sig.t & Criteria & Decision \\
\hline MV & 2,7471 & 0,0075 & $<0,05$ & Significant \\
ROA & 1,5431 & 0,1269 & $>0,10$ & Insignificant \\
EPS & $-0,3387$ & 0,7358 & $>0,10$ & Insignificant \\
BAS & 1,6497 & 0,1031 & $>0,10$ & Insignificant \\
\hline
\end{tabular}

\section{Economic Analysis}

Based on the p-value of the t-test at table 6 , we can conclude which variable is significant and which one is not. The result of REM estimation shows that only MV (Market Value) which affects the holding period of the shares in manufacturing industries listed on JII. MV is significant with positive sign on the length period an investor willing to hold their stocks. The result is in line with the assumption that high market value will trigger people to hold their stocks longer.

The result of this research is also in line with the previous study done by Sari and Abundati (2015) titled "Determinant of the Holding Periods on LQ45 index" since they also point out that market value is significant with positive sign. Thus, market value is a detrimental factor for investor of holding or selling their stocks.

In addition to that, REM estimation shows that ROA is insignificant in affecting the holding period of stocks in manufacturing industry. ROA has no significant effect on the length period of an investor in holding the stocks. This indicates that ROA does not affect investors' decision of holding or selling their stocks longer. It does not matter how much the ROA a company is able to generate since their main concern is the return on the asset they hold now.

The result here is in the contrary of previous study done by Kusumawaty (2016) with the title "The Effect of Securities 
Return, Market Value and ROA on the Holding Period for the Manufacturing Industries Listed under Indonesia Stock Exchange. The study there finds that ROA is significant and positively affects holding period which means when the ROA increases, the stock will be held longer by the investors.

In the same time, the REM estimation result also shows that EPS is insignificant in affecting holding period of stocks in manufacturing industries. EPS is insignificant in affecting the length of investors' holding period. This indicates that EPS does not become factor driving investors' decision whether to hold or sell their assets.

This result supports the previous research done by Hasanah (2016) who wrote a paper with the title "Analysis on Transaction Cost Effect towards Holding Period of LQ45 Shares at Indonesia Stock Exchange" which concludes that EPS is insignificant in affecting holding period. The result goes to the opposite of the assumption that high earning per share could attract more investors and make them willing to hold their assets longer.

Last but not least, REM estimation also shows that BAS (bidask spread) has no effect on the holding period of manufacturing industries' shares. BAS is insignificant on the length the investors' are willing to hold their assets. Therefore, BAS is not the main factor for investor in determining the length of their holding period.

The result here also supports the earlier study done by Perangin-angin and Fauzie (2013) with the title "Analysis of Bid-Ask Spread, Market Value and Variance Return on Holding Period for Mining Industries". The study there recorded that BAS is insignificant so that this variable has no effect on investors' consideration when deciding whether to hold or sell their asset. 


\section{CONCLUSION AND SUGGESTION}

\section{Conclusion}

Based on the analysis done above, we can draw inferences that the independent variables of market value (MV), return on asset (ROA), earning per share (EPS) and bid-ask spread (BAS) are jointly significant in affecting holding period on companies of manufacturing industries listed under Jakarta Islamic Index (JII). However, the effect of market value, return on asset, earning per share and bid-ask spread partially is as the following:

a. Market value is significant and has positive effect on holding period of companies' shares for manufacturing industries listed under Jakarta Islamic Index (JII).

b. Return on asset is not significant in affecting holding period of companies' shares for manufacturing industries listed under Jakarta Islamic Index (JII).

c. Earning per share is not significant in affecting holding period of companies' shares for manufacturing industries listed under Jakarta Islamic Index (JII).

d. Bid-ask spread is not significant in affecting holding period of companies' shares for manufacturing industries listed under Jakarta Islamic Index (JII).

\section{Suggestion}

From the result of this study which has been elaborated above, there are some suggestions that can be made.

1. For investors who wants to make investment on shariah stocks, they should take into consideration the market value since it has proofed that company's market value affects the holding period on stocks of manufacturing industry company.

2. It is also suggested for the next research to add more variables 
or replace the insignificant variables in this research using other variables which are assumed to have impact on holding period, especially the variables which have fundamental value on companies perform. By doing so, it is expected that the result would be more accurate and significant.

\section{REFERENCE}

Arma, V.Y., 2013. Faktor Penentu Holding Period Saham LQ-45 di Bursa Efek Indonesia. Journal of Business \& Banking, 3(2), pp.201-212.

Burhanuddin, S., 2008. Pasar Modal Syariah. Yogyakarta: UII Press.

DSN-MUI. 2014. Himpunan Fatwa Keuangan Syariah. Jakarta: Erlangga.

Hermuningsih, S., 2012. Pengantar Pasar Modal Indonesia. Yogyakarta: UPP STIM YKPN.

Heykal, M., 2012. Tuntunan dan Aplikasi Investasi Syariah. Jakarta: Elex Media Komputindo.

Husnan, S., 1994. Manajemen Keuangan. Yogyakarta: BPFE.

Nahdiatul, A., 2017. Analisis Pengaruh Transaction Cost Terhadap Holding Period Saham-Saham LQ45 di Bursa Efek Indonesia (BEI). Jurnal Akuntansi: Kajian Ilmiah Akuntansi (JAK), 3(1).

Ningsih, T.R. and Haryono, N.A., 2017. Pengaruh Bid-Ask Spread, Market Value Dan Variance Return Terhadap Holding Period Saham Sektor Pertambangan Yang Listing Di Bursa Efek Indonesia (BEI) Tahun 2011-2015. Jurnal Ilmu Manajemen (JIM), 5(3). 
Perangin-angin, N.S. and Syarief, F., 2013. Analisis Pengaruh Bid-ask Spread, Market Value dan Variance Return terhadap Holding Period Saham Sektor Pertambangan. Jurnal Ekonomi dan Keuangan, 1(3).

Rivai, V., Firmansyah, R. and Veithzal,A., Rizqullah. 2010. Islamic Financial Management. (Teori, Konsep, Aplikasi). Bogor: Ghalila Indonesia.

RIyanto, A. and Hutomo, Y.S., 2008. Analasisi Pengaruh Perubahan Market Value dan Laba Per Lembar Saham terhadap Perubahan Holding Period. Saham, KINERJA 12(2), 197-205

Sari, E.W. and Abundati, N., 2015. Determinan Penentu Holding Period pada Indeks LQ45. E-Jurnal Manajemen Unud vol, 4, pp.4529-4558.

Sukirno, S. 2005. Mikro Ekonomi Teori Pengantar. Jakarta: PT Raja Grafindo Persada.

1997. Pengantar Teori Mikro Ekonomi Edisi 2. Jakarta: Grafindo Persada.

Triyono, F., 'Unnurain I., Sutarto. and Rosyadi. I., 2005. Pengantar Teori Investasi dan Pasar Modal. Surakarta: UMS.

Utami, N.L.A.Y. and Sedana, I.B.P., 2016. Pengaruh Spread, Market Value, Variance Return dan Dividend Payout Ratio terhadap Holding Period Saham. Matrik: Jurnal Manajemen, Strategi Bisnis dan Kewirausahaan, pp.168178.

Umam, K., 2013. Pasar Modal Syariah \& Praktek Pasar Modal Syariah. Bandung: Pustaka Setia. 


\section{APPENDIX}

\begin{tabular}{|c|c|c|c|}
\hline No & Code of Companies & Effect (beta) & Constant \\
\hline 1 & ICBP & 8.551977 & 9.852639 \\
\hline 2 & UNVR & 4.672449 & 5.973111 \\
\hline 3 & $\mathrm{INCO}$ & 1.189635 & 2.490297 \\
\hline 4 & INDF & 0.510326 & 1.810988 \\
\hline 5 & AALI & 0.346669 & 1.647331 \\
\hline 6 & ADRO & 0.236706 & 1.537768 \\
\hline 7 & AKRA & -0.316340 & 0.984322 \\
\hline 8 & ANTM & -0.046246 & 1.254416 \\
\hline 9 & WIKA & -0.303428 & 0.997234 \\
\hline 10 & BSDE & 0.295709 & 1.596371 \\
\hline 11 & INTP & -0.650618 & 0.650044 \\
\hline 12 & KLBF & 0.285035 & 1.585697 \\
\hline 13 & LPKR & -0.890401 & 0.410261 \\
\hline 14 & WSKT & -0.585299 & 0.715363 \\
\hline 15 & LSIP & -0.977364 & 0.323298 \\
\hline 16 & UNTR & -0.002000 & 1.298662 \\
\hline 17 & PGAS & -0.020892 & 1.27977 \\
\hline 18 & PTBA & 0.123336 & 1.423998 \\
\hline 19 & PTPP & -0.317227 & 0.983435 \\
\hline 20 & PWON & 0.029130 & 1.329792 \\
\hline 21 & SMGR & -1.006548 & 0.294114 \\
\hline 22 & SMRA & -0.025117 & 1.275545 \\
\hline 23 & MYRX & -1.125673 & 0.174989 \\
\hline 24 & SSMS & -1.193679 & 0.106983 \\
\hline 25 & ADHI & -2.491097 & -1.19044 \\
\hline 26 & ASII & -2.702601 & -1.40194 \\
\hline 27 & LPPF & -3.586441 & -2.28578 \\
\hline
\end{tabular}

